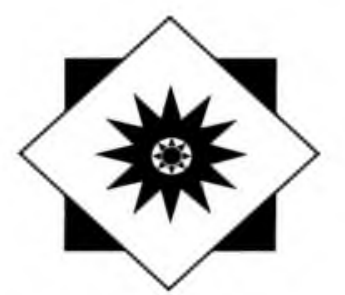

\title{
INNOVATIONS
}

\section{An exercise to test perception of expectations for tenure and promotion}

\author{
By Dennis K. Grumling \\ Assistant Catalog Librarian \\ University of Illinois at Chicago
}

\author{
and Carolyn A. Sheehy \\ Director of Oesterle Library \\ North Central College
}

In an attempt to explore perceptions of how professional activities are valued at three Illinois university libraries, three librarians at the University of Illinois at Chicago developed an exercise to measure, contrast, and compare individual and aggregate perceptions of institutional values assigned to professional services of various kinds. The exercise successfully created an open forum for discussion of otherwise abstract perceptions. We believe that any college or university library could benefit from using the exercise as a communication tool.

The three librarians from UIC were fellows in the 1989-1990 Professional Development Program, sponsored by the libraries of Northwestern University, the University of Chicago, and the University of Illinois at Chicago. A cooperative program established in 1985, it is currently offered on a biennial basis to introduce librarians with seven or fewer years of professional experience in a research library to issues that face research libraries. The nine fellows (three from each participating library) meet approximately two days each month from October through June for thematic seminars. They explore the distinctive approach each institution takes to issues in research librarianship, in areas as varied as preservation, circulation, collection development, information services, and personnel. The program uses seminar discussions, field trips, case studies, research problems, and background readings. Senior staff from each library lead the seminars. The topics are chosen by directors of the program, senior staff members, and the fellows themselves.

The exercise to measure the rankings of professional activities grew out of an investigation by the three fellows of the topic "Leadership at Home and Abroad." Many questions were raised. What is the impact on library operations when librarians are required by the promotion and tenure process to establish national and international reputations? Is there a conflict between support for professional growth and long-term retention? How do institutions cultivate leadership abilities among librarians on their staffs? To initiate discussion of these questions, the fellows from the University of Illinois at Chicago constructed an exercise to determine whether everyone in a particular library viewed the concept of leadership, as reflected in professional activities, in the same way.

Fifteen fictitious descriptions of professional activities were created by the three fellows (the authors of this article and Dana Edwards) to exemplify the professional services, publications, and campus and community services that might be reported on a professional librarian's curriculum vitae. For example, "Chair, Bibliographic Instruction Committee, ACRL," "Member, Board of the Museum of Contemporary Art," "Editor, Handbook for Public Service in Academic Libraries," "Presenter, "Managing Multiple Databases for Public Services in a PC Environment,' ASIS Midyear Meeting," "President, State Library Association," and "Chair, Section on Public Services in Academic Libraries, IFLA" were included in the list. The fictitious curriculum vitae items were intended to reflect a range of activity, from local to international.

The fellows, directors, and governing board members - a total of fourteen individuals-were asked to pretend that they were members of a 
search committee to fill the position of Assistant University Librarian for Public Services for their library. They were instructed to assume that all candidates met the minimum levels of education and experience for the position. Presented with fifteen statements purportedly taken from different curriculum vitae, the participants were asked to rank the importance of each item for their library on a scale of 1 to 5 , where 1 is the lowest and 5 is the highest.

Individual rankings for each item were presented for discussion under the categories of "Fellows," "Directors," and "Institution." Aggregate rankings for the group as a whole were later calculated by the authors. They showed national and international activities to be clearly favored over local and state activities, with all the local activities ranking below the median. Publications were also highly valued, ranking above the median, with both book authorship and editorship in the top quartile. Community service fell into the fourth quartile, while professional service and librarianship were scattered throughout the rankings. All participants ranked lowest a university library committee position, "Secretary, Library Nominations Committee, State University."

Northwestern University and University of Chicago participants ranked highest a service activity, "President-elect, Reference and Adult Services Division, ALA," while the University of Illinois at Chicago participants ranked highest a publication record, "Author, Public Services in Academic Libraries." This may reflect an understanding of the importance placed on publications by the promotion and tenure criteria at the University of Illinois at Chicago. Moreover, the UIC participants ranked all items nearly identically (with a difference of no more than one point). This, too, appears to reflect a clear understanding of the requirements for tenure and promotion at UIC.

The fellows ranked 12 of the 15 items higher than the directors and governors did. This may be attributable to the difference in years of professional experience between the two groups.

This exercise was received enthusiastically by fellows, directors, and governing board members. It generated much discussion, and all participants asked to receive copies of the resulting rankings for further study and possible use in their libraries.

The benefit of this exercise is that it allows perceptions to be measured and then provides a natural forum for examining, comparing, and contrasting those perceptions. Thus, the exercise can be used as a platform for discussion of values and can facilitate communication between staff and management. It also may engender reevaluation of professional activities in job descriptions, search and screen guidelines, and promotion and tenure criteria. Ultimately, this exercise may help build staff and administrative consensus regarding the value of professional activities.

Bobst's first comprehensive effort to train students and scholars to access online resources without mediation by a librarian. At the end of this semester, the library plans to evaluate the success of the workshops and the success students have searching the Classmate databases before deciding whether to continue participation in the Dialog Classmate program. In addition to the experimental workshops, Bobst Library offers a full menu of bibliographic instruction, including sessions for freshman English classes, on-demand instruction for upper-level undergraduate and graduate courses, and classes in library resources for students undertaking dissertation projects in the graduate schools at NYU. - Sandra Naiman

${ }^{1}$ U.S. Department of Education, Digest of Education Statistics 1989 (Washington, D.C.: Government Printing Office, 1989), 393.

${ }^{2}$ Electronic Industries Association, Electronic Market Data Book (Washington, D.C.: Electronic Industries Association, 1990), 25.

${ }^{3}$ Rick Meyer, "From Online to Ondisc," in $C D$ ROM: The New Papyrus (Redmond, Wash.: Microsoft Press, 1986), 509-16. 


\section{Burrage Hall Library collapses. . .}

On January 17, 1991, a section of the east wall of century-old Burrage Hall on the campus of Olivet College in Michigan collapsed. The disaster occurred while work was underway on a $\$ 4.6$ million expansion and renovation of the library. Karen Greer, a student worker, noticed cracks appearing in the library basement and saw dirt falling through the cracks. She alerted Eric Witzke, clerk-of-works for the library project, who warned construction workers to vacate the site and evacuated everyone from the building. Moments later, the 25-by-50-

north and south wings of the building. However, most staff offices, public and technical services, and library utilities - all located in the building's central core-were destroyed. The staff is still assessing the substantial losses, but basic library services were reestablished within ten days, in another building on campus. Fortunately, the library had already planned a temporary move to this alternative site at the end of the school year, in order to be out of Burrage Hall while renovations were completed. That advance planning was tremendously helpful in restoring library operations. Also helpful were area college and university libraries, which extended privileges to Olivet College students, and the Michigan Library Consortium, which loaned an OCLC workstation so that ILL operations could continue.

Despite the damage to Olivet's Romanesque-style library, built in 1890 , construction of the new addition resumed one week after the accident. College officials predict that the expanded library will open in 1992 as scheduled. When the disaster occurred, Olivet's campaign to raise $\$ 4$ million for the expansion had been pledged $\$ 3,225,875$. The

foot stone wall collapsed. There were no injuries.

College officials expect the costs associated with the disaster to be covered by insurance. $\mathrm{Li}$ brary collections are intact (but very dirty) in the college needs to raise the remainder by June 30 , 1991 , in order to qualify for a $\$ 350,000$ challenge grant from the Kresge Foundation.

\section{Reference Materials awards available ...}

The deadline for applying for awards in the National Endowment for the Humanities Reference Materials program is September 1, 1991, for projects beginning after July 1, 1992. The program supports projects that organize essential resources for scholarship and improve access to information and collections. Awards are made in two categories: Tools and Access. Dictionaries, historical or linguistic atlases, encyclopedias, concordances, cata- logues raisonnes, grammars, descriptive catalogs, and databases are eligible in the Tools category. Archival arrangement and description projects, bibliographies, bibliographical databases, records surveys, cataloging projects (for print, graphic, film, sound, and artifact collections), and indexes and guides to documentation are eligible in the Access category. For information: Reference Materials, Room 318, NEH, Washington, DC 20506. 


\section{... and a Furness library is restored}

Restoration of the century-old Furness Library at the University of Pennsylvania has returned "one of the great academic spaces in America" to its original use as the library's reading room.

Ironically, at one time the Philadelphia university considered demolishing the building, which had been altered and was in need of structural repairs. At that time, appreciation of the architect, Frank Furness, had waned. Now, however, he is widely regarded as one of the most important architects of his time (1839-1912).

Restoration of the historic landmark began to take shape after architect Lee G. Copeland became dean of Penn's Graduate School of Fine Arts in 1979. The $\$ 16.5$ million project, planned and executed by Venturi, Scott Brown and Associates with the Clio

Group, restoration consultants, and Marianna Thomas, restoration architect, has been carried out in several phases since 1985 . The challenge was to restore the building as faithfully as possible but also upgrade it to accommodate the university's Fine Arts Library as well as studio and classroom space.

The carefully restored exterior glows with vibrant reds and browns, in contrast to the buffcolored terra cotta and red brick walls of the reading rooms. The skylight and the windows surrounding the great reading room allow light to flood in. These and the frosted glass floors and ceilings in the stacks reveal Furness's plan to capture as much natural light as possible, reducing the need for gas lamps, which gave off fumes that were harmful to books.

The library's design was considered very progressive in 1891. Because Furness had consulted with library experts, he designed a building with separate areas for book stacks, offices, and reading rooms. The different areas are given totally different treatments, and the combination of forms gives the interior robust vitality.

In the rotunda reading room in the newly restored Furness Building at the University of Pennsylvania, the exposed iron beams that support the roof curve down to meet delicate terra cotta floral ornaments that top the sturdy brick pilasters. Photo credit: Dardas.

The Furness Library at the University of Pennsylvania and the Burrage Hall Library at Olivet College are two of the buildings identified by David Kaser in his article on "19th-century academic library buildings" in the September 1987 C $b R L$ News.

\section{Help staff the LIRT booth}

The Library Instruction Round Table (LIRT) needs help staffing the LIRT exhibit booth at the ALA Annual Conference in Atlanta. If you'd like to meet new people and can give two hours of your time to work at the booth, please contact Barbara Burns, Crown Point Community Library, 214 S. Court St., Crown Point, IN 46307, or call (219) 663-0270 by June 7,1991 . You need not be a member of LIRT to volunteer. 